\title{
COVID-19 and climate: global evidence from 117 countries
}

Authors: Simiao Chen ${ }^{1,2, \dagger}$, Klaus Prettner ${ }^{3, \dagger}$, Michael Kuhn ${ }^{4}$, Pascal Geldsetzer ${ }^{1,5}$, Chen Wang $2,6,7,8,{ }^{*}$, Till Bärnighausen ${ }^{1,2,9,10,{ }^{*},}$, David E. Bloom ${ }^{10, \#, \sharp}$

\section{Affiliations:}

${ }^{1}$ Heidelberg Institute of Global Health, Heidelberg University Medical School, Heidelberg University, Heidelberg, Germany.

${ }^{2}$ Chinese Academy of Medical Sciences \& Peking Union Medical College, Beijing, China.

${ }^{3}$ University of Hohenheim, Institute of Economics, Stuttgart, Germany.

${ }^{4}$ Wittgenstein Centre (IIASA, VID/ÖAW, WU), Vienna Institute of Demography, Vienna, Austria.

${ }^{5}$ Division of Primary Care and Population Health, Department of Medicine, Stanford University, Stanford, CA, USA.

${ }^{6}$ National Clinical Research Center for Respiratory Diseases, Beijing, China.

$15{ }^{7}$ Department of Pulmonary and Critical Care Medicine, Center of Respiratory Medicine, ChinaJapan Friendship Hospital, Beijing, China.

${ }^{8}$ Chinese Academy of Engineering, Beijing, China.

${ }^{9}$ Africa Health Research Institute (AHRI), Somkhele, KwaZulu-Natal, South Africa

${ }^{10}$ Department of Global Health and Population, Harvard T.H. Chan School of Public Health, 20 Boston, MA, USA.

$\dagger$ Co-first authors: SC and KP contributed equally to this study

+ Co-senior authors: TB and DB

* Co-corresponding authors:

TB: till.baernighausen@uni-heidelberg.de

CW: wangchen@pumc.edu.cn 
medRxiv preprint doi: https://doi.org/10.1101/2020.06.04.20121863; this version posted June 5, 2020. The copyright holder for this preprint (which was not certified by peer review) is the author/funder, who has granted medRxiv a license to display the preprint in perpetuity. It is made available under a CC-BY-NC 4.0 International license .

\begin{abstract}
:
Visual inspection of world maps shows that coronavirus disease 2019 (COVID-19) is less prevalent in countries closer to the equator, where heat and humidity tend to be higher. Scientists disagree how to interpret this observation because the relationship between COVID-19 and climatic conditions may be confounded by many factors. We regress confirmed COVID-19 cases per million inhabitants in a country against the country's distance from the equator, controlling key confounding factors: air travel, distance to Wuhan, testing intensity, cell phone usage, vehicle concentration, urbanization, and income. A one-degree increase in absolute latitude is associated with a $2.6 \%$ increase in cases per million inhabitants ( $p$ value $<0.001$ ). The Northern hemisphere may see a decline in new COVID-19 cases during summer and a resurgence during winter.
\end{abstract}

One Sentence Summary: An increase in absolute latitude by one degree is associated with a 2.6\% increase in COVID-19 cases per million inhabitants after controlling for several important factors. 
medRxiv preprint doi: https://doi.org/10.1101/2020.06.04.20121863; this version posted June 5, 2020. The copyright holder for this preprint (which was not certified by peer review) is the author/funder, who has granted medRxiv a license to display the preprint in perpetuity. It is made available under a CC-BY-NC 4.0 International license .

Main Text: Many inhabitants of the Northern Hemisphere hope that spread of severe acute respiratory syndrome coronavirus 2 (SARS-CoV-2) and therefore prevalence of coronavirus disease 2019 (COVID-19) will decrease when the weather gets warmer and more sunlight reaches the Earth's surface in spring and summer. Many viral acute respiratory tract infections, such as influenza $\mathrm{A}$ and $\mathrm{B}$, rhinovirus, respiratory syncytial virus, adenovirus, metapneumovirus, and coronavirus, are climate dependent and share the same seasonality (1). Some viruses may have better stability in low-temperature, low-humidity, and low-UV radiation environments $(2,3)$. Thus, an association between hot and humid climate conditions and slower spread of SARS-COV-2 is plausible.

However, as of yet little evidence supports this hypothesis (4). On March 9, 2020, the World Health Organization (WHO) stated that "[f]rom the evidence so far, the COVID-19 virus can be transmitted in all areas, including areas with hot and humid weather" (5). On April 7, 2020, the U.S. National Academies of Sciences, Engineering, and Medicine concluded that "[a]lthough experimental studies show a relationship between higher temperatures and humidity levels, and reduced survival of SARS-CoV-2 in the laboratory, there are many other factors besides environmental temperature, humidity, and survival of the virus outside of the host that influence and determine transmission rates among humans in the 'real world'... with natural history studies, the conditions are relevant and reflect the real-world, but there is typically little control of environmental conditions and there are many confounding factors" (4).

We use global data to examine the relationship between climatic conditions and the spread of COVID-19 controlling for several important confounding factors. We regress the prevalence of COVID-19 (logarithmically transformed) at the country level against the latitude of a country. Latitude captures every climate, because different latitudes on Earth receive different amounts of sunlight. The farther from the equator a country is located, the sharper is the angle of the sun's rays that reach it, the less UV radiation it receives, and the lower the temperature is. Furthermore, latitude also affects humidity, because evaporation is temperature dependent ( 6 ).

To control for key confounders, our analysis includes (i) data on air travel (7) and the distance of a country from Wuhan (8) - the original epicenter of the epidemic-to capture the transmission of SARS-CoV-2 to a country via different routes (9); (ii) vehicle concentration (10) and urbanization (7) to capture differences in the transmission of SARS-CoV-2 within a country (11); (iii) testing intensity $(12,13)$ to control for the vigor of a country's COVID-19 response and for detection bias in cross-country comparisons $(14,15)$; (iv) cell phone usage $(7)$ to control for the speed at which information on behavior change for COVID-19 prevention travels within a country $(11,16)$; and (v) income (7) to control for the availability of general and health systems resources to contain the spread of SARS-CoV-2 (17-19). We imputed missing country covariate data using multiple imputation (20).

Fig. 1 and Table 1 show our results. The farther a country is located from the equator, the more cases the country has in relation to the number of inhabitants. Consistent with our expectations, COVID-19 prevalence is higher in countries that are more open to air travel and have higher 40 vehicle concentrations. In ordinary least squares (OLS) regression, in which we control for all seven potential confounding factors, an increase in the distance from the equator by one degree of latitude is associated with an increase of the prevalence of COVID-19 by about $2.6 \%$ (Table 1, Model 5). This result is highly significant and implies that a country that is located 1000 kilometers closer to the equator could expect 21 percent fewer cases per million inhabitants, other things equal (given that a degree of latitude translates on average into a distance of 111 kilometers). Since the 
medRxiv preprint doi: https://doi.org/10.1101/2020.06.04.20121863; this version posted June 5, 2020. The copyright holder for this preprint (which was not certified by peer review) is the author/funder, who has granted medRxiv a license to display the preprint in perpetuity. It is made available under a CC-BY-NC 4.0 International license.

change in Earth's angle towards the sun between equinox and solstice is about 23.5 degrees, one could expect a reduction in cases per million inhabitants by 46 percent between two seasons. The coefficients of the added quadratic terms are insignificant at the 5\% significance level, indicating that the relationship we are estimating is approximately linear (Table S1). As a robustness check, we further perform robust estimation based on the MM estimator, which is less sensitive to outliers. The size of the coefficient for latitude in the MM estimation is slightly higher than that in the OLS estimation and it remains highly significant (Table S2).

Fig. 1. Scatterplot of the logarithm of cases per million inhabitants against absolute latitude in degrees for the full sample of countries.

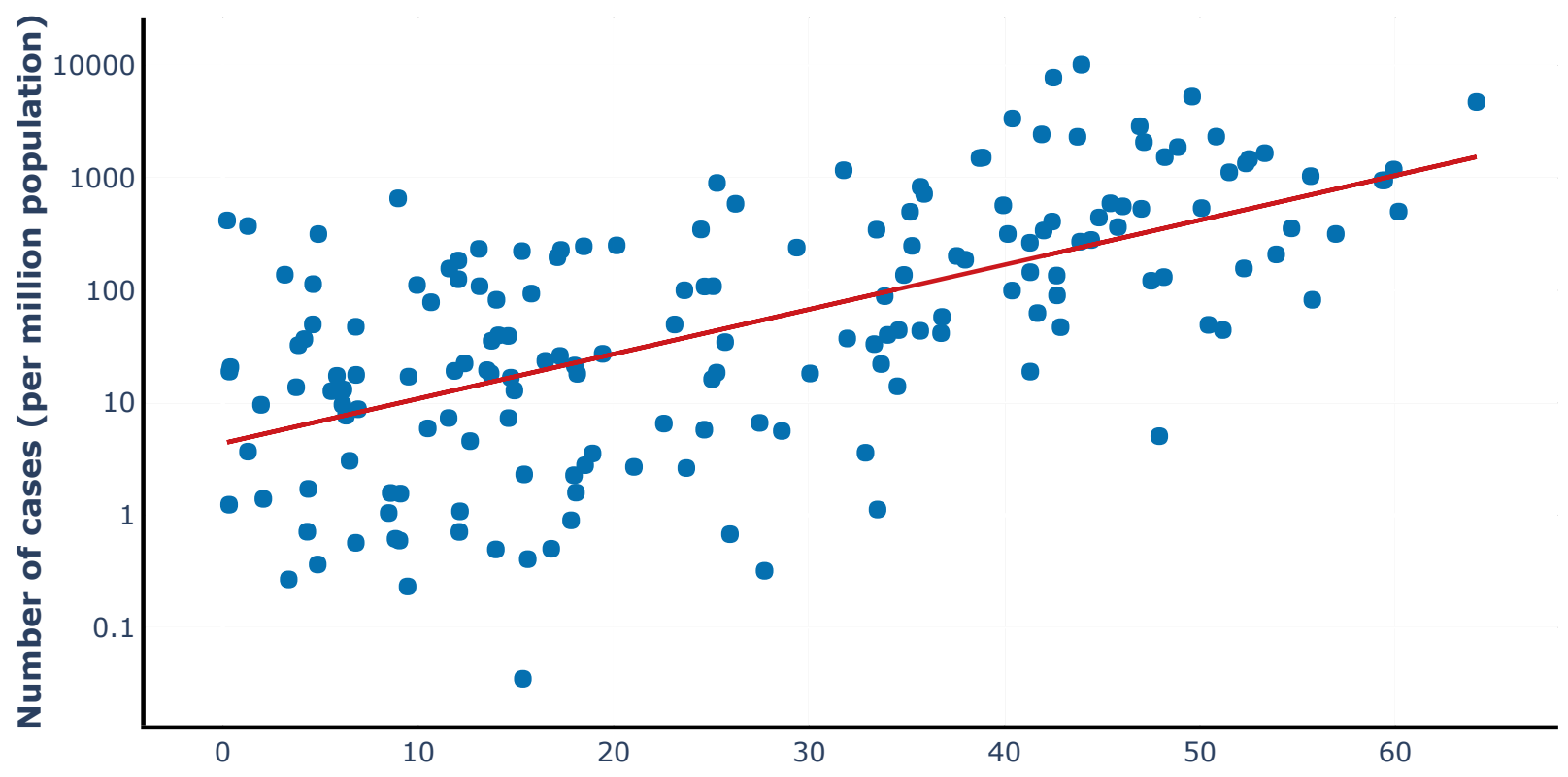

Latitude (absolute value) 
Table 1. Results from Ordinary Least Squares regressions of COVID-19 cases per million inhabitants in a country on the country's latitude and control variables.

\begin{tabular}{|c|c|c|c|c|c|}
\hline & \multicolumn{5}{|c|}{ Cases per million inhabitants } \\
\hline & (1) & (2) & (3) & (4) & (5) \\
\hline & $\begin{array}{l}\text { Coefficient } \\
95 \% \text { CI } \\
\text { p value }\end{array}$ & $\begin{array}{l}\text { Coefficient } \\
95 \% \mathrm{CI} \\
\mathrm{p} \text { value }\end{array}$ & $\begin{array}{l}\text { Coefficient } \\
95 \% \text { CI } \\
\text { p value }\end{array}$ & $\begin{array}{l}\text { Coefficient } \\
95 \% \mathrm{CI} \\
\mathrm{p} \text { value }\end{array}$ & $\begin{array}{l}\text { Coefficient } \\
95 \% \text { CI } \\
\text { p value }\end{array}$ \\
\hline Latitude & $\begin{array}{l}0.066 \\
(0.049 \text { to } 0.083) \\
<0.001\end{array}$ & $\begin{array}{c}0.064 \\
(0.046 \text { to } 0.081) \\
<0.001\end{array}$ & $\begin{array}{c}0.035 \\
(0.021 \text { to } 0.049) \\
<0.001\end{array}$ & $\begin{array}{l}0.031 \\
(0.017 \text { to } 0.046) \\
<0.001\end{array}$ & $\begin{array}{c}0.026 \\
(0.014 \text { to } 0.039) \\
<0.001\end{array}$ \\
\hline Air travel & & $\begin{array}{c}0.120 \\
(0.018 \text { to } 0.222) \\
0.021\end{array}$ & $\begin{array}{l}0.070 \\
(0.026 \text { to } 0.113) \\
0.002\end{array}$ & $\begin{array}{l}0.074 \\
(0.027 \text { to } 0.121) \\
0.002\end{array}$ & $\begin{array}{c}0.035 \\
(-0.014 \text { to } 0.084) \\
0.158\end{array}$ \\
\hline Distance to & & 0.075 & 0.032 & 0.012 & 0.050 \\
\hline Wuhan & & $\begin{array}{c}(0.001 \text { to } 0.149) \\
0.047\end{array}$ & $\begin{array}{l}(-0.034 \text { to } 0.097) \\
0.341\end{array}$ & $\begin{array}{c}(-0.055 \text { to } 0.079) \\
0.721\end{array}$ & $\begin{array}{c}(-0.014 \text { to } 0.114) \\
0.122\end{array}$ \\
\hline $\begin{array}{l}\text { Vehicle } \\
\text { concentration }\end{array}$ & & & $\begin{array}{c}2.449 \\
(1.546 \text { to } 3.352) \\
<0.001\end{array}$ & $\begin{array}{l}2.409 \\
(1.484 \text { to } 3.334) \\
<0.001\end{array}$ & $\begin{array}{c}1.047 \\
(-0.053 \text { to } 2.147) \\
0.062\end{array}$ \\
\hline Urbanization & & & $\begin{array}{l}0.025 \\
(0.012 \text { to } 0.039) \\
<0.001\end{array}$ & $\begin{array}{l}0.021 \\
(0.008 \text { to } 0.034) \\
0.002\end{array}$ & $\begin{array}{c}-0.003 \\
(-0.020 \text { to } 0.014) \\
0.749\end{array}$ \\
\hline $\begin{array}{l}\text { Testing } \\
\text { intensity }\end{array}$ & & & & $\begin{array}{c}-0.006 \\
(-0.011 \text { to }-0.002) \\
0.009\end{array}$ & $\begin{array}{c}-0.006 \\
(-0.010 \text { to }-0.002) \\
0.008\end{array}$ \\
\hline $\begin{array}{l}\text { Cell phone } \\
\text { usage }\end{array}$ & & & & $\begin{array}{c}0.004 \\
(-0.005 \text { to } 0.013) \\
0.351\end{array}$ & $\begin{array}{c}-0.003 \\
(-0.012 \text { to } 0.006) \\
0.529\end{array}$ \\
\hline Income & & & & & $\begin{array}{l}1.048 \\
(0.590 \text { to } 1.506) \\
<0.001\end{array}$ \\
\hline Constant & $\begin{array}{l}2.815 \\
\text { (2.165 to } 3.465)\end{array}$ & $\begin{array}{c}2.030 \\
(0.962 \text { to } 3.098)\end{array}$ & $\begin{array}{c}0.729 \\
(-0.181 \text { to } 1.638)\end{array}$ & $\begin{array}{c}0.994 \\
(-0.234 \text { to } 2.221)\end{array}$ & $\begin{array}{c}-6.372 \\
(-9.880 \text { to }-2.865)\end{array}$ \\
\hline$P$ value & $<0.001$ & $<0.001$ & 0.115 & 0.111 & 0.001 \\
\hline$R^{2}$ & 0.349 & 0.441 & 0.650 & 0.684 & 0.742 \\
\hline Adj. $R^{2}$ & 0.343 & 0.426 & 0.634 & 0.663 & 0.723 \\
\hline$N$ & 117 & 117 & 117 & 117 & 117 \\
\hline
\end{tabular}

Column 1 contains the bivariate specification of the regression of cases per million inhabitants on latitude. The other columns are nested models with control variables. Models (1) through (5) are alternative specifications. The results in this table refer to countries in which more than 100 cases were reported as of April 10, 2020. "Latitude" is the absolute latitude of a country in degrees; "air travel" refers to the number of air passengers per capita in a country; "distance from Wuhan" measures the distance of the capital city of a country from Wuhan, the original epicenter of the epidemic, in thousand kilometers; "vehicle concentration" is the number of registered vehicles per capita; "urbanization" is the percentage of the population living in cities; "testing intensity" is the number of tests per confirmed case; "cell phone usage" refers to the number of cell phones per capita; and "income" refers to the purchasing power adjusted per capita gross domestic product in a country. Robust standard errors are used to account for heteroscedasticity. Missing values were estimated with multiple (15) imputations. CI: confidence interval. 
medRxiv preprint doi: https://doi.org/10.1101/2020.06.04.20121863; this version posted June 5, 2020. The copyright holder for this preprint (which was not certified by peer review) is the author/funder, who has granted medRxiv a license to display the preprint in perpetuity. It is made available under a CC-BY-NC 4.0 International license .

Our results are consistent with the hypothesis that heat and sunlight reduce the spread of SARSCoV-2 and the prevalence of COVID-19. However, our results do not imply that the disease will vanish from the Northern Hemisphere during summer. Rather, the higher temperatures in summer are likely to support public health measures to contain SARS-CoV-2 to some extent. WHO's warning that the virus spreads in all climates must still be taken seriously. Notably, the disease is likely to spread more easily in the Southern Hemisphere over the coming months as it enters fall and winter. Countries in the Southern hemisphere, such as Brazil, Indonesia, or especially South Africa, where the highest number of immunocompromised HIV-positive population live (21), are less prepared to tackle the pandemic than the rich countries of the Northern Hemisphere.

Our analysis has several limitations. First, while our results are consistent with the hypothesis that higher temperatures and more intensive UV radiation reduce SARS-CoV-2 transmission, the precise mechanisms for such an effect remain unclear and may indeed constitute both biological and behavioral factors. For example, people might gather less in crowded indoor places if temperatures are higher, which would reduce transmission. Thus, future research at a later stage of the pandemic should aim at uncovering how the transmission of SARS-CoV-2 is impacted by changes in i) climatic factors such as heat and humidity, ii) geographic factors such as altitude and sunlight intensity, and iii) factors related to human behavior such as social interactions and pollution due to local economic activity at a more disaggregated level. Second, even though we include all countries worldwide for which data for this analysis were available, our final data set included only 117 out of the world's 195 countries, mainly due to the fact that some countries have not yet surpassed the 100 case threshold. Third, while we strive to control for differential testing intensity using a recently compiled and frequently updated data set $(12,13)$, the data on testing intensity could suffer from reporting biases and incomplete coverage of testing approaches. To the extent that testing intensity is a function of a country's income, our analysis controlling for income (Table 1, Model 5) should reduce any biases these data limitations introduce. The fact that column (5) in Table 1 contains a parameter estimate of latitude that is only slightly lower than the one in column (4) and still highly significant is reassuring in this regard. Finally, the distance to the equator only has the same effects to the south and the north at equinox. However, this would be a greater concern if we did the analysis closer to the solstices in summer or in winter. In addition, the effect sizes stayed rather stable over time. In earlier analyses of the data in mid-March, we found similar coefficient estimates.

In sum, we show that an increase in absolute latitude by one degree is associated with a 2-3 percent increase in cases per million inhabitants. Increasing temperatures and longer sunlight exposure during summer in the Northern hemisphere may to some extent boost the effectiveness of public health policies and actions to control the spread of SARS-CoV-2. Conversely, the threat of epidemic resurgence may increase during winter.

\section{References and Notes:}

1. P. D. S. Stewart, Seasonality and selective trends in viral acute respiratory tract infections. Med. Hypotheses 86, 104-119 (2016).

2. K. Chan et al., The effects of temperature and relative humidity on the viability of the SARS coronavirus. Adv. Virol. 2011, (2011).

3. A. Ianevski et al., Low temperature and low UV indexes correlated with peaks of influenza virus activity in Northern Europe during 2010-2018. Viruses 11, 207 (2019). 
medRxiv preprint doi: https://doi.org/10.1101/2020.06.04.20121863; this version posted June 5, 2020. The copyright holder for this preprint

(which was not certified by peer review) is the author/funder, who has granted medRxiv a license to display the preprint in perpetuity.

It is made available under a CC-BY-NC 4.0 International license .

5. World Health Organization. COVID-19 virus can be transmitted in areas with hot and humid climates. March 9, 2020 [cited 2020 March 22]; Available from:

https://www.who.int/emergencies/diseases/novel-coronavirus-2019/advice-forpublic/myth-busters.

6. H. Goosse, P.-Y. BARRIAT, M.-F. LOUTRE, V. ZUNZ, Introduction to climate

4. National Academies of Sciences Engineering and Medicine, "Rapid expert consultation on SARS-CoV-2 survival in relation to temperature and humidity and potential for seasonality for the COVID-19 pandemic (April 7, 2020)," (The National Academies Press, Washington, DC, 2020).

dynamics and climate modeling. (Centre de recherche sur la Terre et le climat Georges Lemaître-UCLouvain, 2010).

7. World Bank. World Development Indicators. 2020 [cited 2020 April 11]; Available from: https://databank.worldbank.org/source/world-development-indicators.

8. Google map. Distance calculator tool. [cited 2020 March 21]; Available from: https://www.mapdevelopers.com/distance finder.php.

9. C. Wang, P. W. Horby, F. G. Hayden, G. F. Gao, A novel coronavirus outbreak of global health concern. The Lancet 395, 470-473 (2020).

10. World Health Organization, "Global status report on road safety 2018: summary," (World Health Organization, Geneva, 2018).

11. S. Chen, J. Yang, W. Yang, C. Wang, T. Bärnighausen, COVID-19 control in China during mass population movements at New Year. The Lancet 395, 764-766 (2020).

12. Wikipedia. COVID-19 testing. April 11, 2020 [cited 2020 April 11]; Available from: https://en.wikipedia.org/wiki/COVID-19 testing.

13. Our World in Data. How many tests for COVID-19 are being performed around the world? April 11, 2020 [cited 2020 April 11]; Available from:

https://ourworldindata.org/covid-testing.

14. J. Cohen, K. Kupferschmidt, Countries test tactics in 'war' against COVID-19. Science 367, 1287-1288 (2020).

15. S. Chen et al., Fangcang shelter hospitals: a novel concept for responding to public health emergencies. The Lancet 395, 1305-1314 (2020).

16. C. J. Wang, C. Y. Ng, R. H. Brook, Response to COVID-19 in Taiwan: big data analytics, new technology, and proactive testing. JAMA 323, 1341-1342 (2020).

17. J. Hanefeld et al., Towards an understanding of resilience: responding to health systems shocks. Health policy and planning 33, 355-367 (2018).

18. K. Blanchet, S. L. Nam, B. Ramalingam, F. Pozo-Martin, Governance and capacity to manage resilience of health systems: towards a new conceptual framework. International journal of health policy and management 6, 431 (2017).

19. D. E. Bloom, J. D. Sachs, P. Collier, C. Udry, Geography, demography, and economic growth in Africa. Brookings Pap. Econ. Act. 1998, 207-295 (1998).

$4020 . \quad$ D. B. Rubin, Multiple imputation for nonresponse in surveys. (John Wiley \& Sons, 2004), vol. 81.

21. UNAIDS. Number of people living with HIV. [cited 2020 April 20]; Available from: http://aidsinfo.unaids.org. 
medRxiv preprint doi: https://doi.org/10.1101/2020.06.04.20121863; this version posted June 5, 2020. The copyright holder for this preprint

(which was not certified by peer review) is the author/funder, who has granted medRxiv a license to display the preprint in perpetuity.

It is made available under a CC-BY-NC 4.0 International license .

Acknowledgments: We would like to thank Ana Abeliansky, Ilan Gutherz, Catherine Prettner, Alfonso Sousa-Poza, and Alexander Zeuner for valuable comments and suggestions.

Funding: PG was supported by the National Center for Advancing Translational Sciences of the National Institutes of Health under Award Number KL2TR003143. DEB was supported by the National Institute on Aging of the National Institutes of Health under Award Number P30AG024409 and by the Value of Vaccination Research Network (VoVRN) through a grant from the Bill \& Melinda Gates Foundation (BMGF Grant OPP1158136), United States. The funders had no role in study design, data collection and analysis, decision to publish, or preparation of the manuscript. The content is solely the responsibility of the authors and does not necessarily reflect the views of the $\mathrm{NIH}$, the VoVRN or the BMGF.

10 Author contributions: SC, KP, TB, DB, and CW contributed to the study concept and design. SC and KP collected data, conducted data analysis, visualized results, and wrote the first draft of the manuscript. SC, KP, TB, DB, and CW contributed to literature review and the interpretation of the data. TB, DB, CW, PG, and MK critically revised the manuscript for important intellectual content. All authors approved the final version. The corresponding authors attest that all listed authors meet authorship criteria and that no others meeting the criteria have been omitted. Competing interests: Authors declare no competing interests.

Data and materials availability: All data are available in the main text or the supplementary materials. 